\section{Commentary: Beyond the horizon of evidence in robotic totally endoscopic coronary artery bypass grafting}

\author{
Aaron J. Weiss, MD, William C. Frankel, MD, and \\ Faisal G. Bakaeen, MD
}

Coronary artery bypass grafting (CABG) has been a mainstay of the cardiac surgeon's armamentarium for decades. In this issue of JTCVS Techniques, Dr Balkhy from the University of Chicago provides an impassioned review of the current state of robotic totally endoscopic coronary artery bypass (TECAB). ${ }^{1}$ Certainly, his enthusiasm for innovation and evolution in the field of coronary revascularization is inspiring. Along with other advocates of robotic TECAB, he highlights the intriguing benefits of the operation, including avoidance of sternotomy, low morbidity and mortality, and faster recovery time. These theoretical benefits catalyzed fervent investigation into robotic $\mathrm{CABG}$ around the turn of the century, culminating in a Food and Drug Administration-sponsored trial. ${ }^{2}$ However, despite considerable initial interest, the adoption of robotic TECAB remains limited to very few dedicated centers.

There are several possible explanations for the lack of widespread adoption of this technique. First, robotic TECAB is a technically complex operation, and although a pathway for acquisition of the requisite skills is outlined, the learning curve remains ill-defined. Second, the overall lack of enthusiasm within the cardiac surgical community has led to insufficient incentive for industry to invest in the necessary technology. In fact, several important

From the Department of Thoracic and Cardiovascular Surgery, Heart, Vascular and Thoracic Institute, Cleveland Clinic, Cleveland, Ohio.

Disclosures: The authors reported no conflicts of interest.

The Journal policy requires editors and reviewers to disclose conflicts of interest and to decline handling or reviewing manuscripts for which they may have a conflict of interest. The editors and reviewers of this article have no conflicts of interest.

Received for publication April 14, 2021; revisions received April 14, 2021; accepted for publication April 22, 2021; available ahead of print April 27, 2021

Address for reprints: Faisal G. Bakaeen, MD, Department of Thoracic and Cardiovascular Surgery, Heart, Vascular, and Thoracic Institute, Cleveland Clinic, 9500 Euclid Ave, Desk J4-1, Cleveland, OH 44195 (E-mail: bakaeef@ ccf.org).

JTCVS Techniques 2021;10:160-1

2666-2507

Copyright (C) 2021 The Author(s). Published by Elsevier Inc. on behalf of The American Association for Thoracic Surgery. This is an open access article under the CC BY-NC-ND license (http://creativecommons.org/licenses/by-nc-nd/4.0/).

https://doi.org/10.1016/j.xjtc.2021.04.022

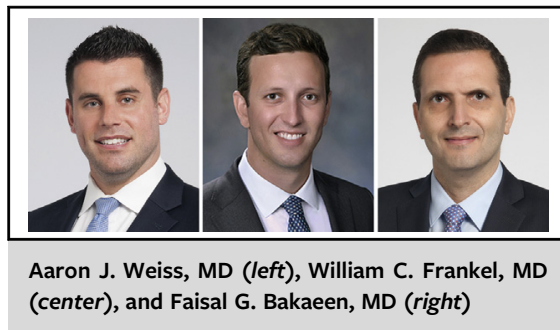

\author{
CENTRAL MESSAGE \\ In the face of emerging technol- \\ ogies, including robotic totally \\ endoscopic coronary artery \\ bypass grafting, it is imperative to \\ maintain the established prior- \\ ities of coronary \\ revascularization.
}

instruments are not compatible with the latest robotic platform (da Vinci Xi). Furthermore, the safety and efficacy of robotic anastomotic devices remain controversial. Although the Multicenter Assessment of Grafts in Coronaries (MAGIC) study ${ }^{3}$ reported comparable patency rates between an automated anastomotic device and hand-sewn anastomoses in open sternotomy, most surgeons remained reluctant, and as a result, it is no longer commercially available.

Last, and perhaps most important, there is a paucity of rigorous prospective data comparing clinically meaningful outcomes between robotic and open techniques for CABG. This "data dilemma" is compounded by the limited generalizability of existing studies that originate from dedicated centers and include highly selected patients who may not mirror the current landscape of patients requiring CABG. A recent report from the Society of Thoracic Surgeons Adult Cardiac Surgery Database revealed that $\sim 95 \%$ of contemporary CABG cases involve multiple bypass grafts. ${ }^{4}$ In contrast, a systematic review of robotic TECAB revealed the use of multiple bypass grafts in only $22 \%$ to $39 \%$ of cases. ${ }^{5}$ On a more encouraging note, $\mathrm{Dr}$ Balkhy alludes to forthcoming data from his experience with 544 patients-including patients with diabetes, obesity, and previous sternotomy- $65 \%$ of whom received multiple bypass grafts. Although a step in the right direction, the $35 \%$ single vessel bypass rate still does not mirror most contemporary $\mathrm{CABG}$ practices, including ours at the Cleveland Clinic, despite an active minimally invasive 
direct coronary artery bypass (MIDCAB) program. Nevertheless, given the limited number of centers currently performing robotic TECAB, along with the considerable variation in technique and patient selection, the lack of equipoise between robotic and open techniques may render a randomized clinical trial unfeasible.

In this context, we find it imperative to maintain the established priorities of CABG: complete revascularization with the use of multiple arterial grafts (MAGs) whenever appropriate and feasible. In addition to the left internal thoracic artery-to-left anterior descending artery anastomosis, ${ }^{6}$ there is a mounting body of evidence demonstrating that both completeness of revascularization $^{7,8}$ and $\mathrm{MAGs}^{8-10}$ provide superior outcomes. Although robotic TECAB may adroitly provide MAGs, the completeness of revascularization with this technique remains concerning. To date, no study has demonstrated that either on- or off-pump robotic TECAB can reliably achieve a degree of surgical revascularization on par with on-pump CABG through a sternotomy. In the context of current evidence, the operation that most reliably achieves these priorities in patients with multivessel coronary disease continues to be an on-pump CABG through a median sternotomy.

\section{References}

1. Balkhy HH. Robotic totally endoscopic coronary artery bypass grafting: it's now or never! J Thorac Cardiovasc Surg Tech. 2021;10:153-7.

2. Argenziano M, Katz M, Bonatti J, Srivastava S, Murphy D, Poirier R, et al. Results of the prospective multicenter trial of robotically assisted totally endoscopic coronary artery bypass grafting. Ann Thorac Surg. 2006;81:1666-74; discussion 1674-5.

3. Balkhy HH, Patel NC, Ramshandani M, Kitahara H, Subramanian VA, Augelli NV, et al. Multicenter assessment of grafts in coronaries: midterm evaluation of the C-port device (the MAGIC study). Innovations (Phila). 2018;13:273-81.

4. D'Agostino RS, Jacobs JP, Badhwar V, Fernandez FG, Paone G, Wormuth DW, et al. The Society of Thoracic Surgeons Adult Cardiac Surgery database: 2018 update on outcomes and quality. Ann Thorac Surg. 2018;105:15-23.

5. Göbölös L, Ramahi J, Obeso A, Bartel T, Hogan M, Traina M, et al. Robotic totally endoscopic coronary artery bypass grafting: systematic review of clinical outcomes from the past two decades. Innovations (Phila). 2019;14:5-16.

6. Loop FD, Lytle BW, Cosgrove DM, Stewart RW, Goormastic M, Williams GW, et al. Influence of the internal-mammary-artery graft on 10-year survival and other cardiac events. N Engl J Med. 1986;314:1-6.

7. Omer S, Cornwell LD, Rosengart TK, Kelly RF, Ward HB, Holman WL, et al. Completeness of coronary revascularization and survival: impact of age and off-pump surgery. J Thorac Cardiovasc Surg. 2014;148:1307-15.e1.

8. Rosenblum JM, Binongo J, Wei J, Liu Y, Leshnower BG, Chen EP, et al. Priorities in coronary artery bypass grafting: is midterm survival more dependent on completeness of revascularization or multiple arterial grafts? J Thorac Cardiovasc Surg. December 20, 2019 [Epub ahead of print].

9. Lytle BW, Blackstone EH, Loop FD, Houghtaling PL, Arnold JH, Akhrass R, et al. Two internal thoracic artery grafts are better than one. J Thorac Cardiovasc Surg. 1999;117:855-72.

10. Bakaeen FG, Ravichandren K, Blackstone EH, Houghtaling PL, Soltesz EG Johnston DR, et al. Coronary artery target selection and survival after bilateral internal thoracic artery grafting. J Am Coll Cardiol. 2020;75:258-68. 